
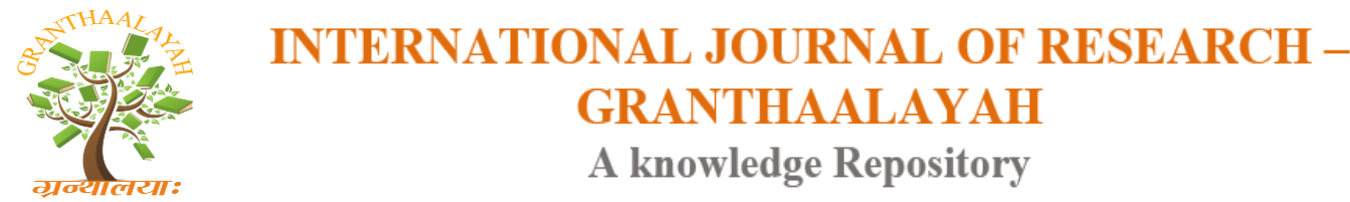

Management

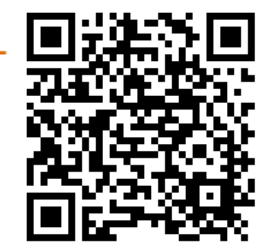

\title{
THE DEVELOPMENT OF MUTUAL FUND INDUSTRY IN INDIA
}

\author{
Poonam Gautam Sharma *1 \\ ${ }^{* 1}$ Department of Commerce, Dev Samaj College for Women, Ferozepur, Punjab, INDIA
}

DOI: $10.5281 /$ zenodo. 58950

\section{ABSTRACT}

The purpose of this article is to present the attributes of mutual fund industry in India, its development since inception with UTI, entry of public sector, private sector and foreign enterprise, various schemes offered by companies especially started to meet small investor's needs. The article also explains the growth aspects of the mutual fund industry along with some guidelines that would result in safe investment and reasonable return.

The main cause of underdevelopment of a nation is its poor capital formation. Mobilization of savings is the backbone of sound financial system and for the development of the economy. The reforms have made the Indian financial system very strong. Mutual fund is one of the emerging financial instruments for small and retail investor and in developing countries like India small investment makes major part of capital. The objective of the study is to reveal the mutual fund industry from its inception to current position. The data used for the study is secondary in nature. To analyze the data various statistical tools like average, percentage and CAGR were used.

Keywords:

Mutual fund industry, growth, financial system, investor.

Cite This Article: Poonam Gautam Sharma, "THE DEVELOPMENT OF MUTUAL FUND INDUSTRY IN INDIA" International Journal of Research - Granthaalayah, Vol. 4, No. 7 (2016): 162-173.

\section{INTRODUCTION}

Mutual fund is a financial intermediary just like a bank because there is perfect transmission of money between holder (saver) and the securities in which the fund invests. Mutual Fund Industry showed the satisfactory growth over the past decade. Mutual Fund defined as an institutional investment vehicle through which customers pool their monetary resources towards the common objectives to spread the risk and to ensure steady return. After investing in mutual fund schemes, the investor need not bother about anything because mutual fund is a professionally managed investment option and also having the professional fund management teams that takes the responsibility of investing in stocks and shares after due analysis and research. Mutual fund is a generic term for various types of investment vehicles such as growth option, index funds, tax 
saving schemes, open-ended investment etc. At Present, there are 42 mutual funds players with several schemes and different options working in competitive market.

\section{THE HISTORY OF MUTUAL FUND INDUSTRY}

Historically, mutual funds in foreign countries began as private enterprise, known as investment trust. It was launched by a single individual who used his financial judgement abilities for the benefit of a group. The AMFI (Association of Mutual Fund in India) has classified the four decades of mutual fund in India into four phases.

Phase I (1963-1987): Growth of UTI: The concept of mutual fund was launched in India with the establishment of Unit Trust of India in 1963. It was establishment by an act of parliament. The first scheme introduced by UTI was US-64 IN 1964, which was the pioneer scheme of the industry in the country. UTI enjoyed the monopoly and continued to provide good returns. Until 1978, the UTI functioned under the control of the Reserve Bank of India (RBI).in 1978. The control transferred to the industrial development Bank of India (IDBI). Since, it was the only one player during that time, as a result, the growth of the industry was synonymous with the growth of UTI.

Phase II (1987-1992): Entry of public sector funds: in 1987, the government allowed the public sector banks and insurance companies to enter the industry due to the liberalization. The state bank of India, was the first bank to set up a mutual fund in November 1987.after that this step was followed by Canara bank (Dec87), LIC (June89), Punjab national bank (aug89), Indian bank(nov89), bank of India (Jun 90), GIC(Dec90), Bank of Baroda(Oct92). Thus, this period was clearly evident the entry of eight new mutual funds, six by public sector banks and two by the insurance corporations.

Phase III (1993-1996): Emergence of private funds: A hallmark period in the mutual fund industry began in 1993 with the entry of private sector and SEBI regulation in the mutual fund industry. The private sector funds came with them latest innovations, investment management techniques and investor servicing techniques. Kothari Pioneer (now merged with Franklin Templeton mutual fund) was the first private sector fund to enter in the market in 1993 as a country's first open ended growth -oriented mutual fund. In 1993-94, five private sector funds launched their schemes followed by six others in 1994-95.

Phase IV (1996-1999): Growth and SEBI regulations: In this phase SEBI set the regulations and uniform standard for all mutual funds operating in India to protect the investors. Liberalization of the economy had increased the competition and growth of the mutual fund industry.

Phase V (1999-2004): This phase was concerned with the growth in terms of both amount mobilized from small investors and assets under management. Earlier UTI functioned and controlled under a separate law of the Indian Parliament but during this phase, UTI was also under the control of SEBI regulations. After that all the new schemes launched by erstwhile UTI had to be SEBI approved. In 2004 SEBI granted mutual funds to invest in overseas securities. 
Present stage of the industry: The industry observed a wave of mergers and acquisitions. The UTI scam in 1998 decline the overall asset under management of the industry but the industry recovered over the years. The mutual fund industry showed the unprecedented growth from 2005 to 2007 with a rate of $32 \%, 62 \%$ and $68 \%$ respectively. The AUM (Asset Under Management) in this industry is Rs. 1,314,532 crore in sep.2015. In 2012-2013, the total gross resources mobilized by mutual fund are Rs.7,267,885 crore in which the resources mobilized by public sector funds Rs. 5,987889 crore and private sector mutual funds Rs.633,350 crore and mobilization of resources by UTI Rs.646,646 crore. According to the monthly number released by the AMFI, the Indian mutual fund industry's AUM rose by Rs.208.40 bn to Rs.12.02 trillion in Feb.2015. According to PwC report, AUM-to-GDP ratio in India only $7 \%$.

\section{REVIEW OF LITERATURE}

Gupta \& Shivani (2011) conducted a study on mutual funds current state and future outlook. They concluded that low awareness level \& financial literacy of customers is the biggest challenge for mutual fund houses. Further the mutual fund houses adopt a comprehensive approach while covering Tier-1 and Tier-2 cities.

M.B. Umarani (2012) analyzed the growth of i Indian mutual fund industry and pointed out that mutual fund industry is illusionary and also there is little doubt on the inherent nature of mutual funds that it's a investment platform for small investors. She suggested that regulators need to make regulation $\&$ policies that will boost the retail participation in the mutual fund industry.

Jani \& Jain (2013) analyzed the relationship between AUM mobilized by mutual fund and GDP growth of the India. They concluded that mutual fund has become a key resource mobilizer for Indian financial system. They suggested that some improvements like proper structure \& regulations are required in the case of black money and also proper regulatory framework for the investor's protection.

Chauhan \& Adhav (2015) studied the recent trends in mutual funds industry in India. The study highlighted that in India investor base of mutual funds is high but when we compare India with other nations, it is still lacking far behind. They suggested that strong regulations, better services to the investors, and high returns could make mutual fund schemes more investor friendly.

Resource Mobilization by Mutual Funds: This section deal with the growth of the Indian mutual fund industry.

Table 1: Assets Under Management (AUM)

\begin{tabular}{|c|c|c|}
\hline Years & $\begin{array}{l}\text { Assets Under Management } \\
\text { (in crores) }\end{array}$ & \% Increase (decrease) \\
\hline 1965 & 25 & \\
\hline 1987 & 4564 & 18156 \\
\hline 1993 & 47000 & 929.80 \\
\hline 2000 & 113005 & 140.43 \\
\hline 2001 & 090587 & -19.83 \\
\hline 2002 & 100594 & 11.046 \\
\hline
\end{tabular}




\begin{tabular}{lll}
\hline $\mathbf{2 0 0 3}$ & 079464 & -21.00 \\
$\mathbf{2 0 0 4}$ & 139616 & 75.69 \\
$\mathbf{2 0 0 5}$ & 149554 & 07.12 \\
$\mathbf{2 0 0 6}$ & 231862 & 55.03 \\
$\mathbf{2 0 0 7}$ & 326388 & 40.77 \\
$\mathbf{2 0 0 8}$ & 505152 & 54.77 \\
$\mathbf{2 0 0 9}$ & 417300 & -17.39 \\
$\mathbf{2 0 1 0}$ & 613979 & 47.13 \\
$\mathbf{2 0 1 1}$ & 700538 & 14.09 \\
$\mathbf{2 0 1 2}$ & 664792 & -5.10 \\
$\mathbf{2 0 1 3}$ & 816657 & 22.84 \\
$\mathbf{2 0 1 4}$ & 905120 & 10.83 \\
$\mathbf{2 0 1 5}$ & 1188690 & 31.33 \\
CAGR & & \\
\hline S04
\end{tabular}

Source: www.amfiindia.com

(Data pertaining to the month of March every year)

The Table 1 shows that in 50 years of existence, the mutual fund industry achieved a CAGR of $24.03 \%$ in assets under management. From a little amount of Rs. 25 crore in 1965, it attained an impressive figure of Rs.13,53,443 crore in year 2016. The table also shows the upwards and downwards trends (in \% form) of AUM in different years.

Table 2: Share of different schemes in AUM of the mutual fund industry (crore)

\begin{tabular}{lllllll}
\hline $\begin{array}{l}\text { Schemes/Year } \\
\text { S }\end{array}$ & Income & $\begin{array}{l}\text { Balance } \\
\text { d }\end{array}$ & ElSS & $\begin{array}{l}\text { Money } \\
\text { market/liqui } \\
\text { d market }\end{array}$ & $\begin{array}{l}\text { Equity/Growt } \\
\text { h funds }\end{array}$ & Gilt \\
\hline $\mathbf{2 0 0 1}$ & 48863 & 19273 & 2523 & 4128 & 13483 & 2317 \\
& $(54 \%)$ & $(21 \%)$ & $(03 \%)$ & $(4.5 \%)$ & $(15 \%)$ & $(2.5 \%)$ \\
$\mathbf{2 0 0 2}$ & 55788 & 16954 & 1768 & 8069 & 13852 & 4163 \\
& $(55 \%)$ & $(17 \%)$ & $(1.7 \%)$ & $(8.2 \%)$ & $(14 \%)$ & $(4.1 \%)$ \\
$\mathbf{2 0 0 3}$ & 47564 & 3141 & 1228 & 13734 & 9887 & 3910 \\
& $(59.8 \%)$ & $(4 \%)$ & $(1.5 \%)$ & $(17.3 \%)$ & $(12.4 \%)$ & $(5 \%)$ \\
$\mathbf{2 0 0 4}$ & 62524 & 4080 & 1669 & 41704 & 23613 & 6026 \\
& $(45 \%)$ & $(03 \%)$ & $(1.2 \%)$ & $(29.8 \%)$ & $(17 \%)$ & $(0.4 \%)$ \\
$\mathbf{2 0 0 5}$ & 47605 & 4867 & 1727 & 54068 & 36757 & 4576 \\
& $(32 \%)$ & $(3 \%)$ & $(1 \%)$ & $(36 \%)$ & $(25 \%)$ & $(3 \%)$ \\
$\mathbf{2 0 0 6}$ & 60278 & 7493 & 6589 & 61500 & 92867 & 3135 \\
& $(26 \%)$ & $(3 \%)$ & $(3 \%)$ & $(27 \%)$ & $(40 \%)$ & $(1 \%)$ \\
$\mathbf{2 0 0 7}$ & 119322 & 9110 & 10211 & 72006 & 113386 & 2257 \\
& $(36 \%)$ & $(3 \%)$ & $(3 \%)$ & $(22 \%)$ & $(35 \%)$ & $(1 \%)$ \\
$\mathbf{2 0 0 8}$ & 220762 & 16283 & 16020 & 89402 & 156722 & 2833 \\
& $(44 \%)$ & $(3 \%)$ & $(3 \%)$ & $(17 \%)$ & $(31 \%)$ & $(1 \%)$ \\
$\mathbf{2 0 0 9}$ & 197343 & 10629 & 12427 & 90594 & 95817 & 6413 \\
& $(47 \%)$ & $(3 \%)$ & $(3 \%)$ & $(22 \%)$ & $(23 \%)$ & $(1.3 \%)$ \\
$\mathbf{2 0 1 0}$ & 311715 & 17246 & 24066 & 78094 & 174054 & 3395 \\
& $(51 \%)$ & $(3 \%)$ & $(4 \%)$ & $(13 \%)$ & $(28 \%)$ & $(1 \%)$ \\
\hline
\end{tabular}




\begin{tabular}{|c|c|c|c|c|c|c|}
\hline 2011 & $\begin{array}{l}291975 \\
(49 \%)\end{array}$ & $\begin{array}{l}18445 \\
(3 \%)\end{array}$ & $\begin{array}{l}25569 \\
(4 \%)\end{array}$ & $\begin{array}{l}73666 \\
(13 \%)\end{array}$ & $\begin{array}{l}169754 \\
(29 \%)\end{array}$ & $\begin{array}{l}3409 \\
(1 \%)\end{array}$ \\
\hline 2012 & $\begin{array}{l}290844 \\
(50 \%)\end{array}$ & $\begin{array}{l}16261 \\
(3 \%)\end{array}$ & $\begin{array}{l}23644 \\
(4 \%)\end{array}$ & $\begin{array}{l}80354 \\
(14 \%)\end{array}$ & $\begin{array}{l}158432 \\
(27 \%)\end{array}$ & $\begin{array}{l}3659 \\
(0.62 \% \\
)\end{array}$ \\
\hline 2013 & $\begin{array}{l}395985 \\
(57 \%)\end{array}$ & $\begin{array}{l}16307 \\
(2 \%)\end{array}$ & $\begin{array}{l}22731 \\
(4 \%)\end{array}$ & $\begin{array}{l}93392 \\
(13 \%)\end{array}$ & $\begin{array}{l}149777 \\
(22 \%)\end{array}$ & $\begin{array}{l}8074 \\
(1.15 \% \\
)\end{array}$ \\
\hline 2014 & $\begin{array}{l}460671 \\
(56 \%)\end{array}$ & $\begin{array}{l}16793 \\
(2 \%)\end{array}$ & $\begin{array}{l}22547 \\
(3 \%)\end{array}$ & $\begin{array}{l}133280 \\
(16 \%)\end{array}$ & $\begin{array}{l}165560 \\
(20 \%)\end{array}$ & $\begin{array}{l}6115 \\
(0.74 \% \\
)\end{array}$ \\
\hline 2015 & $\begin{array}{l}515773 \\
(48 \%)\end{array}$ & $\begin{array}{l}26368 \\
(2 \%)\end{array}$ & $\begin{array}{l}39470 \\
(4 \%)\end{array}$ & $\begin{array}{l}162562 \\
(15 \%)\end{array}$ & $\begin{array}{l}305669 \\
(28 \%)\end{array}$ & $\begin{array}{l}14614 \\
(1 \%)\end{array}$ \\
\hline 2016 & $\begin{array}{l}565459 \\
(46 \%)\end{array}$ & $\begin{array}{l}39146 \\
(3 \%)\end{array}$ & $\begin{array}{l}41696 \\
(4 \%)\end{array}$ & $\begin{array}{l}199404 \\
(16 \%)\end{array}$ & $\begin{array}{l}344707 \\
(28 \%)\end{array}$ & $\begin{array}{l}16306 \\
(1 \%)\end{array}$ \\
\hline CAGR & (16.53\% & $(4.53 \%)$ & $\begin{array}{l}(20.56 \% \\
)\end{array}$ & $(27.42 \%)$ & $(22.45 \%)$ & $\begin{array}{l}(12.97 \\
\%)\end{array}$ \\
\hline
\end{tabular}

Source: www.amfiindia.com

(Data pertaining to the month of March every year)

The Table 2 highlights the share of different schemes in AUM of the mutual fund industry. Table indicates that over the years, income and growth oriented funds are the investor's first choice. The figures shows that the share of GILT Schemes (Debt Funds) in total AUM has decreased from 2003 to 2006 and the same time figures showed that growth funds(Equity Funds) enjoyed increased share in total AUM. But later on trend changed in favor of debt funds. Due to less risky nature of Debt funds, their growth was not bounded in comparison to Equity funds.

Table 3: Cumulative Growth in No. of Schemes

\begin{tabular}{ll}
\hline Years & No. of Schemes \\
\hline $\mathbf{1 9 6 4 - 7 4}$ & 0005 \\
$\mathbf{1 9 7 4 - 8 6}$ & 0010 \\
$\mathbf{1 9 8 9}$ & 0021 \\
$\mathbf{1 9 9 3}$ & 0059 \\
$\mathbf{1 9 9 4}$ & 0167 \\
$\mathbf{1 9 9 9}$ & 0277 \\
$\mathbf{2 0 0 0}$ & 0344 \\
$\mathbf{2 0 0 2}$ & 0417 \\
$\mathbf{2 0 0 4}$ & 0403 \\
$\mathbf{2 0 0 5}$ & 0451 \\
$\mathbf{2 0 0 6}$ & 0592 \\
$\mathbf{2 0 0 7}$ & 0756 \\
$\mathbf{2 0 0 8}$ & 0956 \\
$\mathbf{2 0 0 9}$ & 1001 \\
$\mathbf{2 0 1 0}$ & 0882 \\
$\mathbf{2 0 1 2}$ & 1131 \\
\hline
\end{tabular}




\begin{tabular}{ll}
\hline $\mathbf{2 0 1 3}$ & 1294 \\
$\mathbf{2 0 1 4}$ & 1638 \\
$\mathbf{2 0 1 5}$ & 1884 \\
$\mathbf{2 0 1 6}$ & 2420 \\
\hline
\end{tabular}

Source: www.amfiindia.com

(Data pertaining to the month of March every year)

The Table 3 is related to the growth of schemes. In 1964, there were only 5 schemes but it can be observed that, the number of schemes increased after the entry of private sector in 1993. In present (2016) there are 2420 schemes offered by various AMCs

Table 4: Cumulative Growth in No. of AMCs

\begin{tabular}{ll}
\hline Years & No. of Schemes \\
\hline $\mathbf{1 9 6 4}$ & 01 \\
$\mathbf{1 9 8 9}$ & 08 \\
$\mathbf{1 9 9 3}$ & 09 \\
$\mathbf{1 9 9 6}$ & 26 \\
$\mathbf{2 0 0 0}$ & 33 \\
$\mathbf{2 0 0 5}$ & 30 \\
$\mathbf{2 0 0 6}$ & 30 \\
$\mathbf{2 0 0 7}$ & 32 \\
$\mathbf{2 0 0 8}$ & 35 \\
$\mathbf{2 0 0 9}$ & 38 \\
$\mathbf{2 0 1 0}$ & 38 \\
$\mathbf{2 0 1 1}$ & 41 \\
$\mathbf{2 0 1 2}$ & 44 \\
$\mathbf{2 0 1 3}$ & 43 \\
$\mathbf{2 0 1 4}$ & 46 \\
$\mathbf{2 0 1 5}$ & 43 \\
$\mathbf{2 0 1 6}$ & 42 \\
CAGR & $\mathbf{7 . 6 0 \%}$ \\
\hline
\end{tabular}

Source: www.amfiindia.com

(Data pertaining to the month of March every year)

The Table 4 is related to the number of AMCs in India. It shows that there were only 9 AMCs in 1993, the number of AMCs in India reached the figure of 42 as on $31^{\text {st }}$ march, 2016. The cumulative growth in number of AMCs is $7.60 \%$

Table 5: Share (\%) of Mutual Funds in Total Assets Under Management of the MF Industry

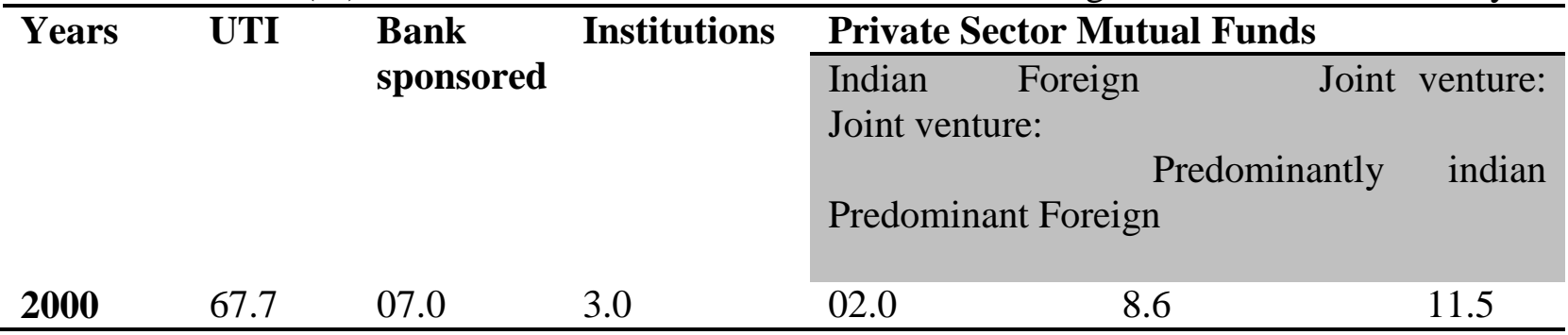




\begin{tabular}{|c|c|c|c|c|c|c|c|}
\hline 2001 & 64 & 03.7 & 3.9 & 03.7 & & 9.5 & 15.2 \\
\hline 2002 & 51.1 & 04.0 & 4.2 & 05.1 & & 15.4 & 20.1 \\
\hline 2003 & 17.0 & 05.6 & 7.4 & 13.0 & & 19.4 & 37.6 \\
\hline 2004 & & 20.1 & 4.7 & 14.2 & 2.6 & 23.7 & 34.6 \\
\hline 2005 & & 19.5 & 2.0 & 20.6 & & 20.6 & 37.3 \\
\hline 2006 & & 19.4 & 2.2 & 22.0 & & 32.0 & 24.4 \\
\hline 2007 & & 16.4 & 3.0 & 24.0 & & 33.0 & 23.6 \\
\hline 2008 & & 15.1 & 2.7 & 30.8 & 5.8 & 30.8 & 14.8 \\
\hline 2009 & & 16.4 & 4.7 & 31.2 & 6.6 & 36.5 & 04.6 \\
\hline 2010 & & 17.4 & 5.6 & 31.5 & 6.7 & 35.8 & 03.0 \\
\hline 2011 & & 17.5 & 1.6 & 34.4 & 7.8 & 36.2 & 02.4 \\
\hline 2012 & & 18.0 & 0.87 & 28.7 & 8.6 & 41.3 & 02.5 \\
\hline 2013 & & 18.5 & 0.87 & 28.1 & 7.0 & 42.1 & 03.2 \\
\hline 2014 & & 18.2 & 1.2 & 25.3 & 6.5 & 45.6 & 3.2 \\
\hline 2015 & & 16.5 & 0.81 & 25.2 & 7.3 & 47.7 & 02.5 \\
\hline 2016 & & 17.94 & 0.99 & 24.7 & 6 & 47 & 1.4 \\
\hline Average & & 14.8 & 2.92 & 21.44 & 6.49 & 30.89 & 14.23 \\
\hline CAGR & & $5.69 \%$ & $-6.31 \%$ & $15.93 \%$ & $8.72 \%$ & $10.50 \%$ & - $11.65 \%$ \\
\hline
\end{tabular}

The table 5 shows the holding pattern of assets under management by various AMCs. After 2003 UTI lost its individuality and consider under bank sponsored mutual funds. The Bank sponsored mutual funds held the $14.89 \%$ of AUM on an average. Institutional mutual funds are not in a strong position; they have only $2.29 \%$ of total AUM of the industry. Private sector is in very strong position as they held $73 \%$ of total AUM. Within private sector AMCs, joint ventures (predominantly Indian) and Indian AMC held 52\% of the total AUM.

Table 6: Share of MFs in Households' Gross Financial Savings

\begin{tabular}{ll}
\hline Years & Share $(\boldsymbol{\%})$ \\
\hline $\mathbf{2 0 0 1}$ & 1.3 \\
$\mathbf{2 0 0 2}$ & 1.8 \\
$\mathbf{2 0 0 3}$ & 1.3 \\
$\mathbf{2 0 0 4}$ & 1.2 \\
$\mathbf{2 0 0 5}$ & 0.4 \\
$\mathbf{2 0 0 6}$ & 3.8 \\
$\mathbf{2 0 0 7}$ & 4.8 \\
$\mathbf{2 0 0 8}$ & 7.7 \\
\hline
\end{tabular}

Mutual Funds other than UTI

Source: SEBI

The table 6 exhibits the share of Mutual funds in households' gross financial savings. It shows the slow but increasing trend over the years. In 2001, the share was only $1.3 \%$ and due to the increasing trend it reached on $7.7 \%$ in 2008. But when we compared it with other countries, it seems that Indian investors still adopting the traditional methods of investment. 
Table 7: AUM to GDP ratio (as of Dec, 2014)

\begin{tabular}{ll}
\hline Countries & Share \\
\hline United States & $91.01 \%$ \\
United Kingdom & $39.55 \%$ \\
Brazil & $42.18 \%$ \\
Spain & $19.48 \%$ \\
Mexico & $9.25 \%$ \\
China & $6.85 \%$ \\
\hline India & $6.57 \%$ \\
\hline
\end{tabular}

Source: www.deloitte.com

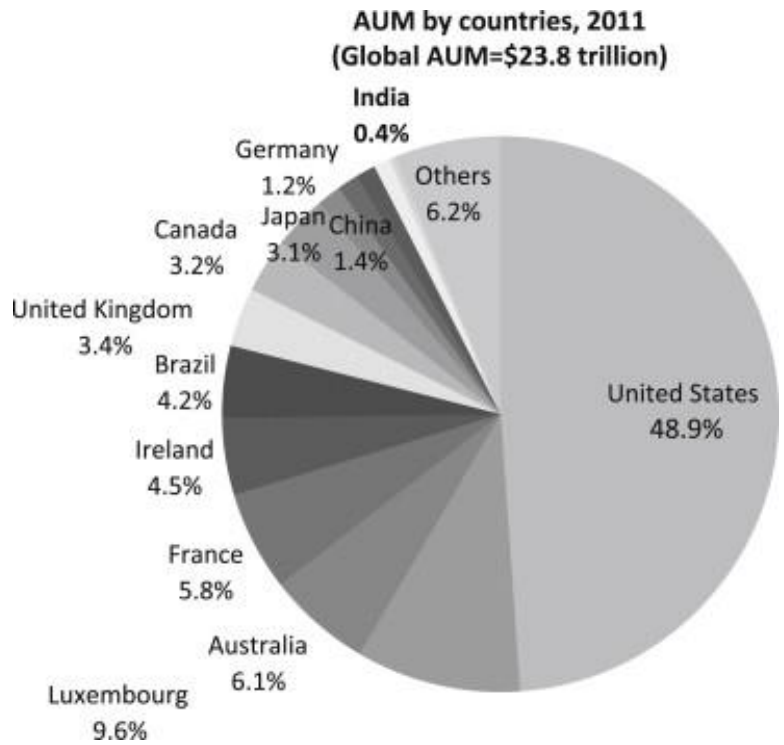

Source: www.deloitte.com

Figure 1: World Mutual Fund Industry

The Table 7 indicates the AUM to GDP of different countries. The developed countries like U.S, United Kingdom, Brazil etc. are the real beneficiaries of the mutual funds. There has been a continuous growth in the mutual fund industry in India but it is still lacking behind in comparison to other countries. Figure 1 also shows that the Indian mutual fund industry is very small at the global level. Its share was only $0.4 \%$ in world mutual fund industry in 2011.

Table 8: BIGGEST FUND HOUSES (as on $31^{\text {st }}$ Mar.2016)

\begin{tabular}{lll}
\hline FUND HOUSE & NO OF SCHEMES & AUM (RS CR) \\
\hline HDFC MUTUAL FUND & 236 & 176,085 \\
$\begin{array}{l}\text { ICICI PRUDENTIAL } \\
\text { MUTUAL FUND }\end{array}$ & 431 & 175,964 \\
$\begin{array}{l}\text { RELIANCE MUTUAL } \\
\text { FUND }\end{array}$ & 289 & 159,370 \\
$\begin{array}{l}\text { BIRLA SUN LIFE } \\
\text { MUTUAL FUND }\end{array}$ & 251 & 136,785 \\
SBI MUTUAL FUND & 169 & 107,327 \\
\hline
\end{tabular}


The Table 8 shows the 5 biggest fund houses of india,with their number of schemes and AUM. As on 31 March,2016 the HDFC mutual fund is the biggest fund house in india with their 236 schemes and 176,085 crore of AUM.

Table 9: Status of Mutual Funds for the period April 1, 2015 to March 31, 2016

(Figures in Rs. Crore)

\begin{tabular}{|c|c|c|c|c|c|}
\hline & Private & Public Sector & Mutual Funds & & Grand Total \\
\hline & A & UTI & Others & Sub-total & $\mathrm{A}+\mathrm{B}$ \\
\hline & & (i) & (ii) & (i) $+(\mathrm{ii})$ & \\
\hline & & & & $\mathrm{B}$ & \\
\hline $\begin{array}{l}\text { Mobilisation of } \\
\text { Funds }\end{array}$ & $11,126,276.54$ & $1,115,822.72$ & $1,523,455.80$ & $2,639,278.52$ & $13,765,555.06$ \\
\hline $\begin{array}{l}\text { Repurchase / } \\
\text { Redemption } \\
\text { Amt. }\end{array}$ & $11,034,883.03$ & $1,100,406.85$ & $1,496,084.65$ & $2,596,491.50$ & $13,631,374.53$ \\
\hline $\begin{array}{l}\text { Net Inflow/ } \\
\text { Outflow (-ve) of } \\
\text { funds }\end{array}$ & $91,393.51$ & $15,415.88$ & $27,371.15$ & $42,787.02$ & $134,180.53$ \\
\hline $\begin{array}{l}\text { Cumulative } \\
\text { Position of net } \\
\text { assets as on }\end{array}$ & $1,022,032.97$ & $94,878.92$ & $115,911.63$ & $210,790.56$ & $1,232,823.53$ \\
\hline March 31, 2016 & $82.90 \%$ & $7.70 \%$ & $9.40 \%$ & $17.10 \%$ & $100 \%$ \\
\hline
\end{tabular}

Net assets of Rs.5391.78 crores pertaining to Funds of Funds Schemes for March 2016 is not included in the above data.

Source: SEBI

The Table 9 exhibits the status of net inflows/outflows of mutual funds in India. Private sector mutual funds cumulative position of net assets are $82.90 \%$ as compared to public sector mutual funds only $17.10 \%$ as on $31^{\text {st }}$ March,2016.

\section{Types of Mutual Fund Schemes:}

There are a large variety of Mutual Fund schemes that satisfy to your needs, whatever your financial position, risk tolerance and return expectations. The MF companies have designed a large quality of investment products.

\section{BASED ON STRUCTURE}

Open -ended and Close-ended funds: Unless something specified on mutual fund, it is openended fund. Open-ended funds remain open for investors to invest in or exit from. This scheme facilitates the investors to buy or redeem the units during any business day at the current Net 
Asset Value (NAV). The close-ended funds are also called fixed maturity fund. Investors can invest only for a short period of time during their 'New Fund Offer' period. Once this offer is over, one cannot invest. Some close ended schemes start as close ended but after the nearer to their redemption date it become open ended schemes.

\section{MUTUAL FUNDS BASED ON FINANCIAL INSTRUMENTS}

\subsection{EQUITY FUNDS}

A mutual fund that mostly invests in stocks is termed as Equity fund. These funds mostly invest in equities with a small portion in money market securities. The main objective behind this is to generate good returns by taking higher risk. So, these funds are only for risk bearing investors. Equity funds can be sub-categorized as -

a) Growth funds

b) Mid- Cap funds

c) Value funds

d) Equity-income funds

e) Index funds and Exchange traded funds

f) Sector funds

g) Equity linked saving schemes

\subsection{DEBT FUNDS (OR INCOME FUNDS/BOND FUNDS)}

Debt funds mainly concentrate their investment in fixed income bearing securities like debentures, government securities etc. Traditionally these funds provide lower returns than equity funds. The main source of their returns is interest receipt and capital gain.

Debt funds can be sub-categorized as -

a) Corporate bond fund

b) Gilt schemes

c) Floating rate schemes

d) Bond index funds

\subsection{HYBRID FUNDS}

Funds in this category are invested in both equities and debt investments. They invest more than $65 \%$ of the corpus in equities and rest in debts. These funds are more stable than equity funds. Hybrid funds can be sub-categorized as -

a) Balanced funds

b) Asset allocation funds

\section{UNITHOLDERS' PROTECTION}

Security Exchange Board of India (SEBI) introduced regulatory measures to protect the interest of small investors that proves it's useful for the long term growth of the industry. SEBI allowed tax deductions on many mutual funds schemes that have inspired the salaried income earners to 
invest in mutual fund schemes. Time to time SEBI has made many changes in MF regulations, to revive the mutual fund industry.

Table 10: Major 6 Changes Introduced by SEBI

\begin{tabular}{|c|c|c|}
\hline Criteria & Before & Now \\
\hline Expense Ratio Charged & $\begin{array}{l}\text { Maximum } 2.5 \% \text { allowed } \\
\text { (depending on the AUM) }\end{array}$ & $\begin{array}{l}\text { Now additional } 30 \text { basis } \\
\text { points are allowed if the } \\
\text { fresh inflow's from smaller } \\
\text { towns }\end{array}$ \\
\hline $\begin{array}{l}\text { Internal Limits on Expense } \\
\text { Ratio }\end{array}$ & $\begin{array}{l}\text { Internal Limits of } 1.25 \% \text { for } \\
\text { Fund Management Charges, } \\
0.5 \% \text { for distribution costs }\end{array}$ & No internal limits now \\
\hline Exit Load go & $\begin{array}{l}\text { went to a separate fund used } \\
\text { for marketing and sales }\end{array}$ & $\begin{array}{l}\text { Added back to Scheme } \\
\text { AUM, but will not benefit } \\
\text { investors because of } \\
\text { equivalent increase in } \\
\text { expense ratio (limited to } 20 \\
\text { basis points) }\end{array}$ \\
\hline $\begin{array}{l}\text { Direct Scheme of Mutual } \\
\text { Funds }\end{array}$ & $\begin{array}{l}\text { Earlier there was no } \\
\text { distinction between a } \\
\text { investment made by agent or } \\
\text { directly with AMC }\end{array}$ & $\begin{array}{l}\text { A new category called } \\
\text { "Direct" has been introduced } \\
\text { which will have a lower } \\
\text { expense ratio. }\end{array}$ \\
\hline Service Tax & Borne by AMC & Borne by Investors \\
\hline $\begin{array}{l}\text { Distinction } \\
\text { between Advisor and } \\
\text { Distributor } \\
\end{array}$ & $\begin{array}{l}\text { There was } \\
\text { distinction earlier }\end{array}$ & $\begin{array}{l}\text { The regulations are now } \\
\text { coming in Advisor and } \\
\text { Distributor will be separated. }\end{array}$ \\
\hline
\end{tabular}

source: http://www.jagoinvestor.com chauhan(n.d)

\section{MAJOR REGULATORY CHANGES DONE BY SEBI}

The table 10 exhibits the 6 major changes done by SEBI to revive the mutual fund industry. In Indian mutual fund industry $87 \%$ of mutual funds money (AUM) comes from top 15 cities, which means that very little amount (only 13\%) of the AUM comes from the small cities in India. If the mutual funds are able to reach to small cities and also get more than $30 \%$ of its AUM from other top 15 cities, they can charge a 30 basis points expense ratio which is higher than its current expense ratio. So, big cities investors will have to face the burden of increased expense ratio.

Earlier there was an internal limit of expense ratio on AMC to charge up to $2.5 \%$ but now SEBI has been removed the internal limits of expense ratio. That means now more commissions to the distributors and more advertisement. For AMCs, this is very encouraging change.

In earlier, when an investor exit prematurely (before 1 year), he was charged an exit load and that money was transferred to a separate fund and used for sales and marketing. But now the entire exit load will be credited to the scheme account. 
In 2013, SEBI has directed to every mutual fund house to offer a direct plan for every fund. Now the investors directly search and buy the mutual funds from AMC. This option is cheaper and makes sense because it does not involve distribution and other charges related with intermediaries.

SEBI has ruled that the service tax that earlier had been paid by the AMCs themselves. But now, it can be passed to the investors.

SEBI has introduced some minimum qualifications, registration and guidelines for financial advisors. The person who want to sell and earn money from financial products, and then he will not be able to advise the clients. The basic advice is considered as the extension of their work.

\section{CONCLUSION}

The mutual fund industry in India is expected a tremendous growth in a few years. The SEBI regulatory framework contributed a lot in indian mutual fund industry but still there are some matters to work on like disclosure and insolvency. In India, still the mutual funds are not recognised as preferable investment in investor's communities. Fund houses adopt a comprehensive approach and contribute towards financial inclusion. The distribution channels have not been utilised to a significant level. Overall, we can conclude that mutual fund industry has to make efforts towards the stable growth and sustained profit rather than short term growth.

\section{REFERENCES}

[1] Gupta, shivani, (2011) "Indian Mutual Fund Industry: Current State and Future Outlook", Indian journal of finance, vol.5, no.4, 2011, pp. 38-48.

[2] M.B. Umarani, (2012) "Growth of Indian mutual fund industry in the past decade", journal of business and management, vol.6, no.2, dec.2012, pp27-29.

[3] Jani, Dhimen \& Jain, Rajeev, (2013) "Role of mutual funds in Indian financial system as a key resource mobilizer", Journal of research in management \& technology, vol.2, dec.2013, pp. 85-91.

[4] Chauhan, M. \& Adhav, M. (2015) "Recent trends in mutual fund industry in India", International Journal of Science, Technology \& Management, vol.04, april 2015, pp.5461.

[5] Das,Geeta (n.d). A to Z of mutual funds- An ideal investment option for investors. Article retrived from http://manupatra.com

[6] Chauhan, M. (n.d.). 6 changes in mutual funs done by SEBI recently-good or bad? Retrived from http://www.jagoinvestor.com

[7] http://www.brownconsultancy.com/mffaq-schemetypes.aspx

[8] http://timesofindia.indiatimes.com/

[9] http://www.itsallaboutmoney.com/

[10] http://www.indianmirror.com/indian-industries/mutual-fund.html

[11] http://www.business-standard.com/markets-mutual-funds

[12] www.deloitte.com

[13] www.amfiindia.com

[14] http://www.ici.org/research 